\title{
Dynamic Planning for Product Platform and Module Based on Graph Theory
}

Yongming $\mathrm{Wu}^{1,2}$, Han $\mathrm{Zhang}^{1}$, Lifei $\mathrm{Luo}^{1}$, Yanxia $\mathrm{Xu}^{1}$

${ }^{1}$ Modern Manufacturing Key Laboratory of Guizhou University, Guizhou Guiyang 550025, China. E-mail: wu20811055@163.com

${ }^{2}$ Public Big Data Key Laboratory of Guizhou Province, Guizhou, Guiyang, 550025, China.

\begin{abstract}
Aiming at the problem of platform planning and module identification in product family design, modular theory, implementation methods and objectives are studied in mass customization(MC), and a dynamic planning model is established for product platform and module. Firstly, the versatility and physical consolidation of existing variants are analyzed and expressed using directed and undirected graphs. And then a dynamic planning algorithm, in which the platform threshold and the module boundary parameters are set dynamically based on market demands, is proposed in product platform and module design. Secondly, potential parts are extracted for more variant products in product family design. Finally, the effectiveness of the proposed approach was demonstrated by the dynamic planning for parts of different humidifiers.
\end{abstract}

Keywords: Product platform, Modularization, Graph theory, Dynamic planning

\section{Acknowledgments}

This work was supported by the National Natural Science Foundation of China (grant no. 51505094), the Guizhou Provincial Natural Science Foundation, China (no. [2016]1037), Applied basic research program of major projects in Guizhou(JZ[2014]2001) and talent introduction research program of Guizhou University(2014)60.

\section{References}

[1] SEDLAK J,MALASEK J,ONDRA M,POLZER A.(2016).Development and production of prototype model of axial fan.Manufacturing Technology, Vol. 16, No.2,pp.436-444. Univerzita J. E., Purkyne.

[2] KIM S., MOON S. K. (2016). Sustainable platform identification for product family design. Journal of Cleaner Production, vol.143,pp.567-581. Elsevier Ltd, United Kingdom.

[3] MAVRIDOU E., KEHAGIAS D. D., TZOVARAS D.,HASSAPIS G.(2013).Mining affective needs of automotive industry customers for building a mass-customization recommender system. Journal of Intelligent Manufacturing, vol.24,no.2,pp. 251-265. Springer New York LLC,USA.

[4] BERNATIKOVÁ A.,NOVÁK P.(2016).Optimizing the production of porous alloys based on TiSi. Manufacturing Technology, Vol. 16, No.5,pp.871-874. Univerzita J. E., Purkyne.

[5] LI S., MIRHOSSEINI M.(2012). A matrix-based modularization approach for supporting secure collaboration in parametric design. Computers in Industry, vol.63,no.6,pp.619-631. Elsevier B.V., Netherlands.

[6] ALGEDDAWY T., ELMARAGHY H. (2013). Reactive design methodology for product family platforms, modularity and parts integration.CIRP Journal of Manufacturing Science and Technology, vol.6,no.1, 3pp.4-43. Elsevier Ltd, United Kingdom.

[7] RUSNÁKOVÁ S, ALEXANDER ČAPKA,FOJTL L.,MILAN ŽALUDEK, RUSNÁK V. (2016) Technology and mold design for production of hollow carbon composite parts. Manufacturing Technology, Vol. 16, No.4,pp.799804. Univerzita J. E., Purkyne.

[8] HANAFY M., ELMARAGHY H. (2017). Modular product platform configuration and co-planning of assembly lines using assembly and disassembly. Journal of Manufacturing Systems,vol. 42,pp.289-305. Elsevier B.V., Netherlands.

[9] BEZÁK J.,BEZÁK P., VAJDOVÁ A. (2015). Structural design of blocking element of magnetic cycloid transmission. Manufacturing Technology, Vol. 15, No.3,pp.263-266. Univerzita J. E., Purkyne.

[10] DURÁN O., PÉREZ L., BATOCCHIO A. (2012). Optimization of modular structures using Particle Swarm Optimization. Expert Systems with Applications,vol.39,no.3, pp.3507-3515. Elsevier Ltd, United Kingdom.

[11] DOU R., ZONG C., NAN G.(2016).Multi-stage interactive genetic algorithm for collaborative product customization. Knowledge-Based Systems, vol.92, pp.43-54. Elsevier B.V., Netherlands. 
[12] BROWNING, T.R. (2001). Applying the Design Structure Matrix to System Decomposition and Integration Problems: A Review and New Directions. IEEE Transactions on Engineering Management, 48(3),292-306. Institute of Electrical and Electronics Engineers Inc.USA.

[13] HASSAN M., HOGG G. L. (1987). A review of graph theory application to the facilities layout problem. Omega, vol.15,no.4, pp.291-300,1987. Elsevier B.V., Netherlands.

[14] CHENG Q., ZHANG G., GU P., SHAO X. (2012). A product module identification approach based on axiomatic design and design structure matrix.Concurrent Engineering,vol.20,no.3,pp.185-194. Springer-Verlag London Ltd, United Kingdom.

[15] LI S., MIRHOSSEINI M.(2012).A matrix-based modularization approach for supporting secure collaboration in parametric design.Computers in Industry,vol. 63,no.6, pp.619-631. Elsevier B.V., Netherlands.

[16] HWANG S. C., CHOI Y. (2011). Modular design of a product to maximize customer satisfaction with respect to body size: A case study for designing office chair. International Journal of Precision Engineering and Manufacturing, vol.12,no.5,pp.791-796. Elsevier B.V., Netherlands.

[17] CAROLINE I.,MAGYAR, VINCENT P. (2017). Utility of the cbcl dsm-oriented scales in assessing emotional disorders in youth with autism. Research in Autism Spectrum Disorders, pp.11-20. Elsevier B.V., Netherlands. 